\title{
Çok Kültürlülük ve Ayrımcılık Arasında: Avrupa Ülkelerinin Entegrasyon Politikalarında Eğitim Alanı
}

\section{Veysel Erat}

Öz: Giderek artan uluslararası insan hareketliliği göçü birçok açıdan inceleme nesnesi haline getirmiştir. Farklı boyutları bulunan göç ve göçmen politikalarının en önemli alanlarından birisi entegrasyondur. Entegrasyonun asimilasyondan çokkültürlülüğe uzanan birçok tanımı vardır. Üzerinde uzlaşı sağlanmış bir tanımı bulunmayan entegrasyona ilişkin çeşitli göstergeler oluşturulmuştur. Eğitim alanı birbirinden farklı endekslerde yer alan ortak bir entegrasyon alanıdır. Çalışmanın amacı Avrupa'da uygulanan göçmen entegrasyon politikalarının eğitim alanı üzerinden incelenmesidir. Çalışma üç bölüme ayırılmıştır. Birinci bölümde entegrasyon kavramı ve alternatif yaklaşımlar ele alınmıştır. Sonraki bölümde entegrasyon türleri ve göstergeleri incelenmiştir. Son bölümde Avrupa ülkelerinin eğitimde geliştirdiği entegrasyon politikaları iki alt başlıkta çözümlenmiştir. Sonuç olarak Avrupa ülkelerinin bir kısmının çokkültürlü, diğer bir kısmının ayırımcı modeli benimsedikleri ortaya konmuştur.

Anahtar Kelimeler: Avrupa, entegrasyon, eğitim, çokkültürlülük, ayırımcilık.

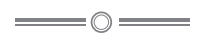

\section{Between Multiculturalism and Discrimination: Education Area in the Integration Policies of European Countries}

Abstract: Increasingly, international human mobility has made migration the subject of investigation in many respects. Integration is one of the most important areas of migration and immigration policies. There is not a single definition of integration ranging from assimilation to harmony.However, various indicators of integration have been established and education is one of them. In this context, the aim of this study is to examine integration policies in Europe in the field of education. The study was divided into three sections. In the first chapter, the concept of integration and alternative approaches are discussed. In the next section, integration types and indicators are examined. In the last chapter, the

\footnotetext{
* Dr. Öğr. Üyesi Bitlis Eren Üniversitesi, iiBF, Kamu Yönetimi, ORCID: 0000-0002-0735-5432, veyselerat@hotmail.com.
} 
integration policies developed by European countries in education are analysed under two sub-headings. As a result, while some of the European countries have adopted multicultural education model, others have adopted discriminatory model.

Keywords: Europe, integration, education, multiculturalism, discrimination.

\section{Giriş}

Dünya nüfusunun neredeyse 3,3'üne tekabül eden uluslararası göçmen nüfusu (IOM, 2018), göçün içinde bulunduğumuz yüzyılın kalıcı bir özelliği olduğunu göstermek açısından yeterlidir. Uluslararası insan hareketliliğinde yaşanan artış devletleri ilgili politikaları konusunda yeniden düşündürmeye devam etmektedir. Genel olarak göç ve göçmen politikaları olarak sınıflandırabileceğimiz politikaların kaynak, transit ve hedef ülkeler açısından birçok boyutu bulunmaktadır. Çalışmanın odağında yer alan hedef ülkeler açısından ne kadar göçmene izin verileceği, daimi olarak kalma niyetinde olan göçmenlerin temel yaşamsal olanaklardan vatandaşlık elde edinceye kadar geçireceği süreçte kendilerini ve ev sahibi ülkeyi ilgilendiren bir dizi politika konusu bulunmaktadır. Bu süreçte geliştirilen politikaların doğrudan ya da dolaylı olarak entegrasyon konusuyla ilgili olduğunu söylemek yanlış olmayacaktır.

Entegrasyon gerek siyasi gerekse de akademik açıdan sıklıkla kullanılan ancak üzerinde uzlaşmaya varılmış tanımı bulunmayan bir kavramdır. Entegrasyonun özellikle karar alıcılar tarafından farklı şekilde yorumlanması hem politikaların içeriğini hem de göçmenlerin beklentilerini etkilemektedir. Ancak genellikle ulusal saik ile tanımlanan kavramın uluslararası girişimler yoluyla içeriğinin doldurulmaya çalışıldığı görülmektedir. Göçü yönetilebilir kılmak ve ortak bir mülteci ve göç rejimi oluşturmak çabasında olan Birleşmiş Milletler gibi küresel ya da Avrupa Birliği gibi bölgesel oluşumlar göçmenlerin varılan ülkede elde etmesi gereken olanaklar üzerinde durmaktadırlar. Diğer taraftan akademik yazının ve çeşitli küresel düzeyde araştırma gruplarının entegrasyona ilişkin göstergeler üzerinde çalıştığı görülmektedir. Aşağıda detaylı bir şekilde incelenmekle birlikte siyasal katılım (Yontar ve Savut, 2018; Demirkanoğlu, 2017), toplumsal entegrasyon (Şahin, 2010), göçmen çocuklarının eğitimi (Özservet, 2015) ve vatandaşlık (Erat ve Özkaya, 2017; Yıldız, 2017) gibi konular önde gelmektedir.

Araştırmalara konu olan entegrasyon göstergelerinin farklılaştığı gözlemlenmekle birlikte birçoğu ortak göstergelere vurgu yapmaktadır. Yukarıda sayılanların yanı sıra, işgücü piyasalarına katılım, sağlık, aile birleşimi ve ayırımcılık karşıtı politikalar temel göstergeler arasındadır. Bu çalışmanın sorunsalı olan eğitim politikaları entegrasyon göstergelerinden önemli bir alanı oluşturmaktadır. Çalışmanın temel amacı Avrupa ülkelerinde uygulanan eğitim politikalarının göçmenler açısından ne kadar kapsayıcı olduğunun ortaya 
konulmasıdır. Diğer bir ifadeyle Avrupa ülkelerinde göçmenlerin entegrasyonunu sağlamaya yönelik eğitim politikalarının analizini yapmak hedeflenmektedir.

Castles ve Miller (2008: 361) devletleri genel olarak entegrasyon konusunda kademeli ayırımcı, asimilasyoncu ve çokkültürcü ülkeler olmak üzere üçe ayırmışlardır. Bu çalışmada Avrupa ülkeleri için yalnızca çokkültürcü ve kademeli ayırımcı kavramlaştırması kullanılmıştır. Bunun nedeni çalışmanın eğitim alanı ile sınırlandırılmasıdır. Diğer bir ifadeyle, göçmenlerin entegrasyonuna ilişkin bilgi edinilecek sağlık, siyasal katılım, daimi ikamet gibi göstergeler incelenmediğinden asimilasyoncu model kullanılmamıştır. Nitekim bir ülkenin asimilasyoncu olup olmadığı ancak diğer göstergelerin incelenmesiyle mümkündür. Fakat eğitim alanının çokkültürcü ya da ayırımcı bir yapı arz edip etmediği bu politikaların içeriğinin incelenmesiyle anlaşılabilir.

Çalışma genel olarak üç ana bölüm olarak kurgulanmıştır. Birinci bölümde entegrasyon kavramı ve alternatif yaklaşımlar üzerinde durulmuştur. ikinci bölümde entegrasyon türleri ve göstergeleri incelenmiștir. Son bölümde Avrupa ülkelerinin eğitimde geliştirdiği entegrasyon politikaları analiz edilmiştir. Ülkelere ilişkin veriler Göçmen Entegrasyon Politika Endeksi'nden (Migrant Integration Policy Index-MIPEX) alınmıştır. Avrupa Birliği fonu ile finanse edilen ve Barselona Uluslararası ilişkiler Merkezi (Barcelona Centre for International Affairs- CIDOB) ile Göç Politikaları Grubu (Migration Policy Group- MPG) tarafından yürütülerek hazırlanan veriler, 38 ülkede 8 ana gösterge üzerinden derlenmiştir. Çalışmada Avrupa ülkeleri için temel sorunsal olarak belirlenen eğitim alanı çokkültürcü ve ayırımcı modeller kullanılarak çözümlenmeye çalışılmıştır.

\section{Entegrasyon Kavramı ve Alternatif Yaklaşımlar}

İngilizcede tümlemek (Oxford, 2018), Türkçede (TDK, 2018) bütünleşmek olarak açıklanan entegrasyon kavramı, göçmenlerin katıldıkları topluma eklenerek o toplumun parçası olmalarını anlatmak için kullanılmaktadır. Ancak bir toplumun parçası olmanın koşulları, bütünleşmenin sınırları ve bütünleşmeye karar verenlerin kimler olduğu soruları kavramın göz ardı edilmeyecek muğlak yönleridir. Bu nedenle entegrasyon kavramı objektif ya da ampirik olarak tanımlanabilecek statik bir kavram değil, manası sürekli değişebilen, süreçleri evirilen ve içinde bulunduğu koşullara bağlı (siyasal, toplumsal, tarihsel, hukuksal vb.) toplumsal bir projedir (Unutulmaz, 2015: 143-144). Literatürde entegrasyonun üzerinde uzlaşıya varılmış bir tanımı bulunmamaktadır. Gerek politikacılar gerekse bilim insanlarının yapmış oldukları tanımlamaların bir kısmı çokkültürcü bir anlayışa diğer bir kısmı ise asimilasyona tekabül etmektedir (Özmen, 2012: 64). Diğer bir ifadeyle, kavramın anlamı göçmenin egemen kültür içinde asimile olmasından göçmenlerin kimliklerini koruyarak ev sahibi ülke vatandaşlarıyla eşit sayılmasına kadar uzanır (Keskin, 2011: 27).

$\mathrm{Bu}$ durum göçmenlerin entegrasyondan beklentilerini ülkeden ülkeye farklılaştırdığı gibi aynı zamanda ülkelerin entegrasyon ile amaçladıkları ve bu 
bağlamda uygulamaya soktukları politikaları da farklılaştırmaktadır. Kavramın algıdaki tezahürleri entegrasyona alternatif kavramların kullanılmasına yol açmıştır. Asimilasyon, akültürasyon, seperasyon, segregasyon, adaptasyon bunlardan bazılarıdır. Asimilasyon terimi ile ilişkili imgeler, göçmenleri ve mültecileri tek yönlü, tek yanlı bir uyum süreci ile toplumla kaynaștırmayı gerektirmektedir. Yeni gelenler kendine özgü dilsel, kültürel ve sosyal özelliklerini bırakmalı, bunun yerine ana akımın değerlerini ve uygulamalarını benimsemelidir. Böylece göçmen içinde bulunduğu çoğunluk nüfusundan ayırt edilemez hale gelir. Bazen bu sürecin birden fazla nesil alması beklenir. Devlet egemen dilin kullanımı konusunda ısrar ederek ve göçmen çocukların normal devlet okullarına katılımını mecburi kılarak bu sürece elverişli koşullar meydana getirmeye çalışır. Asimilasyon, 1960'lara kadar Birleşik Krallık, ABD, Avustralya ve Kanada dahil birçok göç ülkesinde hakim yaklaşım olmuştur ve bazı Avrupa ülkelerinde, özellikle de Fransa'da hala önemlidir (Castles, Korac, Vasta, \& Vertovec, 2002: 116).

Akültürasyon (Kültürel Etkileşim) ise göçmenlerin kültürel aidiyetlerini reddetmeksizin içinde yaşadığı kendisine yabancı kültürün değerlerini kabul etmeleri ve davranışlarında rehber almalarıdır (Akşar, 2016: 9). Akültürasyonda göçmenlerin göç ettiği ülkenin dilini ve aynı zamanda baskın kültürel değerlerini ve uygulamalarını öğrenmesi beklenmektedir (Castles, Korac, Vasta, \& Vertovec, 2002: 117). Segregasyon (yalıtma) ve seperasyon (ayrışma) kavramlarının ikisi de göçmen grupların hakim toplumda mekansal, yapısal ve kültürel açılardan ayrı olmalarını ifade etmektedir. Segregasyonda azınlık kültür çoğunluğa karşı tecrit edilmiş ya da sınırlı bir alana hapsedilmiştir. Seperasyonda ise azınlık grup asimile olmamak amacıyla kendilerini hakim toplumdan mekansal ve sosyo-kültürel açılardan uzakta tutmaktadır (Özmen, 2012: 56-57). Parçalara ayırarak asimilasyon (segmented assimilation); göçmenlerin bir bütün olarak toplumun üyeleri haline gelmeyeceğinden hareketle daha ziyade ırk ya da etnik köken ve sınıf temelinde tanımlanan belirli bölümleriyle asimile edilebileceklerini ifade etmektedir. Yapısal ve fonksiyonel asimilasyon göçmenlerin bazı faaliyet alanlarına (örneğin, işgücü piyasası veya eğitim sistemi) başarılı bir şekilde katılabileceğini vurgularken, başka alanlardan (siyasi sistem gibi) dışlanmaya devam etmesini anlatmaktadır. Benzer bir kavram olan hariç tutma/dışlama (exclusion) da belirli bir toplumun üyeliğinin göstergelerinden göçmenlerin dışlanmasına göndermede bulunmaktadır. Bunun antitezine içerme(inclusion) denilmektedir ve göçmenlerin alt politikalara katılımlarına açıklığı ifade etmektedir. Son olarak göçmenlerin vatandaş olmadan önceki entegrasyon süreçlerini anlatan ve diğer kavramlara nazaran nispeten tarafsız olan yerleşim (settlement) ve denizen (denizenship) gibi kavramlar kullanılmaktadır. Yukarıda anılan kavramlar göç ve entegrasyon ile ilgili güncel sosyal bilim literatüründe yer alan belirli terimlere ilişkin yalnızca fikir vermektedir. Bazı terimlerin birden fazla anlamı vardır. Terimlerin kesin anlamı ve önemi konusunda neredeyse hiç bir fikir birliği yoktur (Castles, Korac, Vasta, \& Vertovec, 2002: 115-118). 
Bu durum ifade edildiği üzere genellikle devletlerin entegrasyona faklı anlamlar yüklemesi ve göçmenlerin beklentilerinin de karşılıklı olarak farklılaşabilmesinden kaynaklanmaktadır. Castles ve Miller (2008: 361-365) ülkelerin göçmenler karşısında geliştirdikleri tepkileri üçe ayırmıştır. Birincisi, Kademeli Ayırımcı Model'dir. Bu model, ulusu doğum ve soy birliği üzerinden tanımlayan devletlerde görülmektedir. Ev sahibi toplum göçmenleri ve çocuklarını ulusun üyeleri olarak kabul etmek istemezler. Ayrımcı modeli benimseyen ülkeler genellikle aile birleşimini kısıtlamakta, oturma statüsünü vermek istememekte, vatandaşıı ve siyasal katılım gibi durumlarda dışlayıcı bir tutum takınmaktadır. Bu modelde göçmenler sivil topluma işçi, tüketici ve ebeveyn olarak bağlıdır. İkincisi göçmenlerin kendi dilsel, kültürel ve sosyal özelliklerini bırakmalarının beklendiği Asimilasyoncu Model'dir. Bu modeli benimseyen ülkelerde uygulanan entegrasyon politikaları asimilasyonun daha yavaş ve kibar biçimi şeklindedir. Son kategori Çokkültürlülük Modeli'dir. Bu modelde göçmenlerin ev sahibi topluma ait belli değerlere uyulması arzulansa da kendi farklıııklarını bırakmaları beklenmez. Çokkültürcü anlayışı benimseyen ülkelerde göçmen olarak gelmeye izin verilmesiyle başayan süreç, devlete ve vatandaşlığa erişime kadar uzanan bir içermeye sahiptir.

\section{Entegrasyon Türleri ve Göstergeleri}

Göçmenlerin ulus-devlet temelinde vardıkları ülkelerde sosyo-politik topluluğun üyesi olma sürecini açıklayan entegrasyon kavramı, ilk zamanlar asimilasyon odaklı geliştirilen sonraki süreçte çokkültürcülüğe kayan birbirinden farklı türleri içerisinde barındırmaktadır. 1920'lerde etkili olan Chicago Sosyoloji Okulu'nun geliştirdiği “ırk ilişkileri döngüsü” yaklaşımı; (i) temas, (ii) çatışma, (iii) uyum ve (iv) asimilasyon olarak derecelendirdiği modelde herhangi bir dış etken olmadığı müddetçe asimilasyonun kaçınılmaz olduğunu savunmuştur. Amerikan "erime potası" (melting pot) düşüncesinin bir ürünü olan evrimsel modele göre, döngünün son aşamasında etnik gruplar arasındaki farklılıkların ortadan kalkması beklenmektedir (Martikainen, 2010: 265). Benzer bir yaklaşımı benimseyen Milton Gordon, 1964'de yazdığı eserde asimilasyonun yedi alt sürecini, genel ya da özel isimlerini, şu şekilde açıklamıştır: (i) kültürel parametrelerin ev sahibi topluma göre değiştiği kültürel ve davranışsal asimilasyon; (ii) ev sahibi topluluğun kurumlarına kitleler halinde dâhil olunmasına göre yapısal asimilasyon; (iii) evliliklerin çoğalmasına göre evlilikle asimilasyon; (iv) göçmenin kendisini ev sahibi toplumun parçası olarak görmesine göre kimliğe dayalı asimilasyon; (v) önyargının ortadan kalkmasına göre tutumsal asimilasyon; (vi) ayırımcılığın ortadan kalkmasına göre davranışsal kabullenme asimilasyonu ve (vii) değer ve güç çatışmasının ortadan kalkmasına bağlı olarak vatandaş olma yoluyla asimilasyon (Gordon, 1964: 71).

Göçmenlerin vardıkları ülke ile gireceği etkileşimi hesaba katmayan ve ev sahibi toplumu statik sayan bu görüşler, entegrasyonu evrimsel bir süreç olarak açıkladıkları ve asimilasyonu kaçınılmaz bir sonuç olarak gördükleri için 
eleştirilmişlerdir. Sonraki çalışmalar entegrasyonun sonuçları itibariyle hem göçmen hem de ev sahibi ülke açısından karmaşık bir süreç olarak görmüştür. Martikainen (2010: 265-266) göçün toplumun tüm alanlarını etkilediğinden hareketle entegrasyonu kültürel, yapısal ve siyasal olarak tasnif etmiştir. Buna göre, kültürel entegrasyon; hem göçmenin vardığı ülkenin değerleri, kural ve davranış modelleriyle ilişkisi hem de ev sahibi ülkenin göçmenlerin kültürel olgularına karşı geliştirdikleri tepkileri açıklamaktadır. Yapısal entegrasyon ise göçmenlerin ekonomi ve eğitim gibi kurum ve organizasyonlarda yer bulabilmeleri ve kendilerinin de bu tür kurumları oluşturabilmelerini anlatmaktadır. Son olarak siyasi entegrasyon, ev sahibi ülke vatandaşlarının sahip olduğu yasal haklardan faydalanabilme, siyasal olarak karar alma süreçlerine katılabilme ve nihayetinde vatandaşlık elde edebilme gibi göçmeni ev sahibi topluma tamamen katan durumları kapsamaktadır. Benzer bir şekilde entegrasyona ilişkin yaklaşımları üç kategoride inceleyen Castles, Korac, Vasta, \& Vertovec (2002: 138) yapısal entegrasyon kavramı yerine sosyal entegrasyon kavramını kullanmışlardır. Ancak entegrasyona ilişkin alt kategorileri daha geniş bir yelpazede açıklamışlardır. Bunlar; eğitim ve istihdam göstergeleri, sosyal entegrasyon göstergeleri, sağlık göstergeleri, yasal entegrasyon göstergeleri, siyasal entegrasyon göstergeleri ve doğurganlık, ölüm oranları, yaşam beklentileri, hizmetlerden yararlanma gibi durumları içeren genel entegrasyon göstergeleridir. Yazarlar anılan göstergelerin kapsamlı veya eksiksiz olarak değerlendirilmemesi gerektiğini belirtmişlerdir. Yazarlara göre, entegrasyon göstergelerinin oluşturulmasında ve değerlendirilmesindeki başlıca problemler, bu alanda daha fazla çalışmaya ihtiyaç olduğunu göstermektedir ve entegrasyon için bir dizi kabul edilmiş gösterge oluşturmak ancak bu şekilde mümkün olabilir. (Castles, Korac, Vasta, \& Vertovec, 2002: 131-132).

Nitekim diğer yazar ve kurumların entegrasyon göstergeleri incelendiğinde ortak olanlar bulunmakla birlikte birbirinden farklı göstergeler de ölçülme konu olmuştur. Örneğin $O E C D, A B$ ve OECD ülkelerindeki entegrasyon politikalarını şu göstergeler üzerinden incelemiştir: Nüfusa ilişkin veriler, ikamet süreleri, hane halkının kompozisyonu, işgücü piyasalarına katılım, yapılan işlerin ve kalitesi, eğitim ve öğretim, hane halkı geliri, sağlık, sivil katılım ve sosyal uyum (OECD ve European Union, 2015). Yine başka bir dizinde Eurostat'ın göç istatistiklerine dayanılarak göçmenlerin entegrasyonu; işgücü piyasası, istihdam koşulları, eğitim, konut ve yaşam koşulları, yoksulluk ve sosyal dışlanma riski, aktif vatandaşlık üzerinden incelenmiştir (European Union, 2017). Biraz daha kapsamlı bir ölçüm yapan MIPEX tüm AB Üye Devletleri, Avustralya, Kanada, İzlanda, Japonya, Güney Kore, Yeni Zelanda, Norveç, İsviçre, Türkiye ve ABD'de uygulanan cari entegrasyon politikalarını 8 alan olarak sınıflandırmıştır (MIPEX, 2015a). 167 alt göstergeden oluşan bu politikalar; işgücü hareketliliği, sağlık, eğitim, aile birleşimi, daimi ikamet, ayrımcılıkla mücadele, siyasal katılım ve vatandaşlığa erişim politikalarıdır (MIPEX, 2015b). Görüldüğü üzere birbirinden farklı kategorileri bulunsa da birçok ortak gösterge üzerinden göçmenlerin 
vardıkları toplumla entegre olup olmadıkları ölçülmektedir. Dizinlerdeki ortak göstergeler devletler tarafından pratikte uygulanan entegrasyon politikalarından çıkarılmıştır. Farklı göstergeler ise araştırmacıların bakış açısından ve çoğu zaman göçmenin beklentileri doğrultusunda olması gerekenden süzülmüștür. Ancak tüm dizinlerde görüldüğü üzere çalışmanın temel sorunsalı olan eğitim alanı yer almıştır.

\section{Avrupa'da Eğitim Alanında Geliștirilen Entegrasyon Politikaları}

Toplumsal bütünleşmenin ön koşullarından biri olan eğitim, gerek asimilasyoncu gerekse de çokkültürcü modeli benimseyen devletler açısından kullanılabilir bir politika alanıdır. Özellikle göçmen çocukların aldığı eğitim, gelecekteki entegrasyon biçimlerini belirlemektedir (Koçak \& Gündüz, 2017: 76). Aralarında sıkı bir ilişki olan göç ve eğitim konusunda (UNESCO, 2017), çoğu Avrupa ülkesinde göçmen çocukları yerli çocuklara nazaran çok daha düşük eğitim seviyesine sahiptir. Göçmen çocukların eğitime erişimleri neredeyse tüm Avrupa'da garanti altına alınmasına rağmen bu politikaların sosyo-ekonomik dezavantajları ve dilsel zorlukları tamamıla gözeten bir anlayışta değildir (Jacobs, 2013:). Çalışmanın bu bölümünde özellikle MIPEX verilerine dayanarak Avrupa'daki eğitimsel entegrasyon politikaları Castles ve Miller tarafından devletlerin göçmenlere karşı geliştirdikleri tutuma göre yaptıkları sınıflandırmadan kademeli ayırımcı model ve çokkültürcü model yaklaşımlarıyla ele alınacaktır.

MIPEX ülkelerin entegrasyon politikalarını her politika alanı için ayrı ayrı ve genel olarak ölçmektedir. Eğitim politikalarının alt göstergeleri dört ana boyuttan oluşmaktadır: (i) Erişim boyutunda; okul öncesi ve zorunlu eğitime erişim, zorunlu eğitimin yasal bir hak olup olmaması, göçmen çocukların önceki eğitimlerinin değerlendirilip değerlendirilmediği, zorunlu olmayan eğitime erişim, mesleki ve yükseköğretime erişim politikalarına bakılmaktadır. (ii) Hedeflenen İhtiyaçlar boyutunda; her düzeyde eğitime rehberliğin olması, eğitim dilinin öğrenilmesi için destek sağlanması, göçmenlerin gözlemlerinin neler olduğunun izlenmesi, göçmen çocukların eğitim düzeyinin ölçülmesi ve göçmenlerin öğrenme ihtiyaçlarına cevap verecek öğretmen yetiştirme programlarının olması durumlarına bakılmaktadır. (iii) Yeni Fırsatlar; boyutunda göçmenlerin dillerini ve kültürlerini öğrenmeleri için desteklenmesi, göçmen öğrencilerin ayrımcılığa maruz kalmamaları için entegrasyon politikalarının geliştirilmesi, göçmen ebeveyn ve topluluklarının desteklenmesi, göçmenlerin öğretmen işgücüne kazandırılması için önlemlerin geliștirilmesi göstergelerinden hareket edilmektedir. Son olarak (iv) Herkes için Kültürler Arası Eğitim boyutunda; çeşitliliği yansıtıp yansıtmadığından hareketle okul müfredatlarına ve öğretmen eğitimlerine bakılmaktadır. Ayrıca günlük okul yaşamının çeşitliğe hitap edip etmemesi ve devletin bilgiye erişimi desteklemesi de bu boyutta yer almaktadır (MIPEX, 2018: 19). 
MIPEX genel olarak ülkeleri altı gruba ayırmıştır. Bunlar çok olumsuz (0), olumsuz (1-20), biraz olumsuz (21-40), orta düzey (41-60), biraz olumlu (61-79) ve olumludur (80-100).Tüm politika alanları genel olarak değerlendirildiğinde ülkelerin hiçbirinin olumsuz, çok olumsuz ve olumlu grup içinde yer almadığı görülmektedir (MIPEX, 2015d). Eş deyişle hiçbir ülke entegrasyon konusunda tamamen açık olmadığı gibi büsbütün olumsuz bir durum da söz konusu değildir. Eğitimsel entegrasyon göstergesini incelediğimizde ülkeler dört gruba ayrılmıștır (Tablo 1). MIPEX'in kendi sınıflandırmasına göre birinci grupta yer alan ülkeler biraz olumlu; ikinci grupta yer alan ülkeler orta düzey, üçüncü grupta yer alan ülkeler biraz olumsuz ve son grupta yer alan ülkeler olumsuz kategorisinde yer almaktadır. Çalışmada birinci ve ikinci gruptaki ülkeler çokkültürcü, üçüncü ve dördüncü gruptaki ülkeler ise ayırımcı model içinde değerlendirilmiştir.

Tablo 1. Avrupa Ülkelerinin Eğitimsel Entegrasyon Politikası Sıralaması.

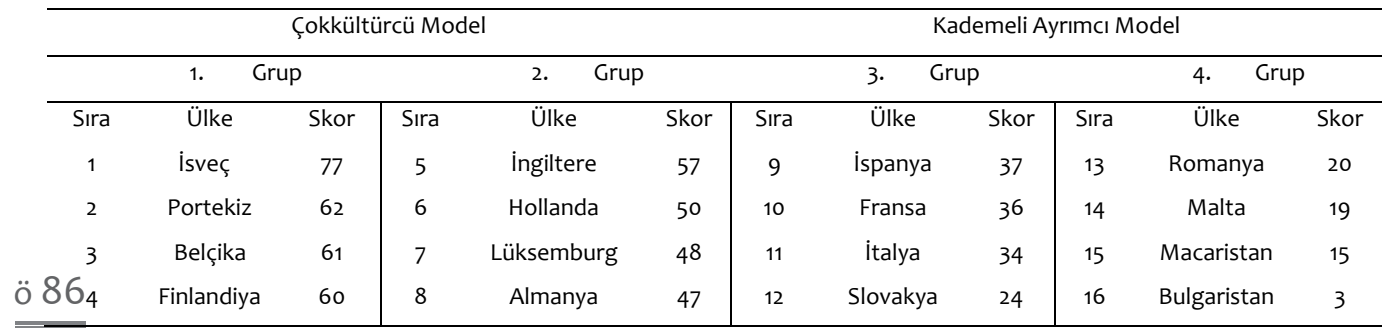

Kaynak: MIPEX verilerine dayanılarak yazar tarafından derlenmiştir.

\section{Avrupa'da Çokkültürcü Eğitim Politikaları}

MIPEX verilerini politika alanları için belirlediği göstergeler üzerinden oluşturmaktadır. Dolaysıyla hiçbir ülkede uygulanmayan bir politikanın MIPEX verilerinde yer alması söz konusu değildir. MIPEX'te bütün ülkelerdeki en olumlu politikalar, diğer bir deyişle bugün eğitim alanındaki en iyi senaryoda ülkede yaşayan her çocuk anaokulundan üniversiteye gidebilir ve elinden gelenin en iyisini yapabilir. Aynı sosyo-ekonomik geçmişe sahip sınıf arkadaşları ile eşit ölçülerde yararlanır. Ailelerinin göçmenlik deneyimi nedeniyle farklı ihtiyaçları varsa, ek desteklerden faydalanır. Öğretmenler bu ihtiyaçları tanımak ve onun için yüksek beklentileri belirlemek için eğitilmiştir. Göçmenler dili öğrenmek ve ustalaşmak için ekstra dersler ve öğretim hakkına sahiptir. Tüm öğrenciler, ailelerinin dili ve kültürü ile ilgili sınıflara kayıt yaptırabilir. Okul müfredatları, ders kitapları, program ve işe alım uygulamalarında kültürlerarası bir yaklaşım benimsenir. Göçmenler, tüm öğrenciler ve görevliler ile birlikte, farklı bir toplumda nasıl yaşanacağını öğrenir (MIPEX, 2015C).

Tablo 1'den anlaşılacağı üzere hiçbir Avrupa ülkesinde bütünüyle çokkültürcü bir eğitim anlayışı mevcut değildir. Biraz olumlu kategorisinde yer alan Avrupa ülkeleri; İsveç (77), Norveç (65), Portekiz (62), Belçika (61), Finlandiya'dır (60). En yüksek skora sahip olan İsveç göçmenlerin tüm okul 
düzeylerine erişimini garantileme konusunda yetersiz olsa da zorunlu eğitimden sonra göçmen öğrencilerin çıraklık ve yükseköğretime erişimini kolaylaştıran özel önlemler vardır. Okullar ve belediyeler yeni gelenleri bilgilendirmek, yönlendirmek ve ileri düzeyde ikinci bir dil edinmelerini sağlamakla yükümlüdür. iki dil hizmeti sunan okullar devlet tarafından ayrıca mali olarak desteklenmektedir. Okullarda yeni gelenler ile anne ve babalarıyla iletişim kurulması için tercüman kullanma hakkı tanınmaktadır. Ayrıca göçmen öğrencilerin isteğe bağlı olarak özel ihtiyaçlarına yönelik kapsamlı eğitimler bulunmaktadır. Öğrencilerin öğrenme ve toplumsal entegrasyonu için kendilerinde bulunan beceriler birer fırsat olarak değerlendirilir ve bu bağlamda bir tutum sergilenmesi konusunda okullar teşvik edilir. Öğrencilere anadil kursları seçme hakkı tanınmaktadır. İsveç'te Ulusal Eğitim Ajansı ders kitapları ve materyallerini, 'eşit saygı ve hoşgörü' anlayışına uyarlar ve böylece kültürler arası eğitimi gerçeğe dönüştürmeye çalışır. İsveç'in eğitim göstergelerinden (eğitime erişim, hedeflenen ihtiyaçlar, yeni fırsatlar, kültürlerarası eğitim) zayıf olduğu boyut göçmenlerin eğitime erişim politikalarıdır (MIPEX, 2015e).

Bu boyut birçok Avrupa ülkesinde sorunlu alanlardan birisidir. Bunun dışında tabloda birinci grupta yer alan diğer ülkeler incelendiğinde Norveç'in ayrıca 'yeni fırsatlar' boyutunda biraz zayıf kaldığı görülmektedir (MIPEX, 2015f). Portekiz ve Belçika'nın da eğitime erişim ve yeni fırsatları değerlendirme boyutları yetersizdir (MIPEX, 2015g; MIPEX, 2015h). Aynı grupta yer alan Finlandiya ise kültürler arası eğitim konusunda kendi grubu içindeki diğer ülkelerin gerisindedir. Her ne kadar okul müfredatlarında "Kültürel Kimlik ve Enternasyonalizm" öncelikli bir vurgu olsa da okullar uygulamada esnek davranmaktadır ve kültürlerarası eğitimin gerçekliğe dönüştürülme çabası güçlü değildir (MIPEX, 2015i).

Tablo 2. Birinci Grup Ülkelerin Göçmen Eğitim Gösterge Skorları.

\begin{tabular}{lllll}
\hline Ülke & Erişim & $\begin{array}{l}\text { Hedeflenen } \\
\text { ihtiyaçlar }\end{array}$ & Yeni Fırsatlar & $\begin{array}{l}\text { Kültürlerarası } \\
\text { Eğitim }\end{array}$ \\
\hline İsveç & 58 & 90 & 80 & 80 \\
Norveç & 42 & 90 & 50 & 80 \\
Portekiz & 67 & 70 & 40 & 70 \\
Belçika & 42 & 65 & 53 & 85 \\
Finlandiya & 67 & 90 & 45 & 40 \\
\hline
\end{tabular}

Kaynak: MIPEX verilerine dayanılarak yazar tarafından derlenmiştir.

Çokkültürcü modelin ikinci grupta yer alan Avrupa ülkeler Estonya (58), İngiltere (57) Hollanda (50), Danimarka (49) Lüksemburg (48), Avusturya (47) ve Almanya'dır (47). Estonya eğitime erişim, yeni fırsatlar ve kültürler arası eğitim boyutlarında orta düzeyde yer almaktadır. Ancak çokkültürcülüğün önemli bir 
göstergesi olan hedeflenen ihtiyaçlar boyutunda en yüksek skora sahip ülkelerden biridir (Tablo 3). Yeni gelenlerin okuldaki ihtiyaçları için gerekli tüm önlemler alınmaktadır. Hizmet öncesi ve hizmet içi eğitimle tüm öğretmenler çok kültürlü öğrenme ortamlarına hazırlanmaktadır. Göçmenlere Estonya dilinin öğrenilmesi için iyi bir eğitim verilmektedir. Göçmenlerin gitmiş olduğu okullar ekstra fonlanmakta ve bazı okullarda zorunlu olmamakla birlikte göçmen çocukların ebeveynleri için başlangıç programları düzenlenmektedir (MIPEX, 2015j). Hedeflenen ihtiyaçlar konusunda aynı skora sahip olan Danimarka'da da göçmenlerin eğitimi yoğun bir şekilde desteklenmekte ve kaliteli dil kursları olanakları sunulmaktadır. Ancak kültürlerarası eğitim boyutu açısından müfredatlar farklı kültürleri tanımaya elverişli değildir. Kültürlerarası eğitim 'Batı'ya ait değerleri öğrenmek anlamına gelmektedir. Bu nedenle Danimarka tüm MIPEX ülkeleri içinde bu boyutta 30. sırada yer almaktadır (MIPEX, 2015k).

İngiltere ise kültürlerarası eğitim boyutunda en iyi skora sahiptir. Bütün öğrenciler aldıkları vatandaşlık eğitimi dersleriyle kültürel çeşitlilik hakkında farkındalık elde edebilmektedirler. 2010 yılında çıkarılan bir yasa ile farklı ırksal, kültürel, dinsel ihtiyaçları karşılamakla vazifelendirilen okullar topluluk uyumunu gerçekleştirmek için görevlendirilmişlerdir. Okul müfredatlarına kimlik ve çeşitlilik konusu göz ardı edilmemektedir. Ingiltere kültürlerarası bir eğitim anlayışı benimsese de yeni fırsatlar boyutunda oldukça geridir (MIPEX, 2015I). İngiltere ile aynı durumda olan Hollanda yeni fırsatlar açısından oldukça geridedir. Göçmen öğrencilerin becerilerinin kullanılması konusunda isteksizlik söz konusudur. Göçmen ailelerin okul aktivitelerine ve yönetişime katılmalarını sağlayan programlar son dönemlerde kaldırılmış ve entegrasyon destekleri kesilmiştir (MIPEX, 2015m). İkinci grup ülkeler genel olarak değerlendirildiğinde eğitime erişim konusunda orta düzeyde bir durum söz konusudur ve göçmenlerin durumlarını fırsata çevirebilecek politikalarda yetersizlikler vardır. Birinci ve ikinci grup ülkelerden kültürlerarası eğitim ve hedeflenen ihtiyaçlar konusunda genel olarak olumlu politikalar vardır.

Tablo 3. İkinci Grup Ülkelerin Göçmen Eğitim Gösterge Skorları.

\begin{tabular}{lllll}
\hline Ülke & Erişim & $\begin{array}{l}\text { Hedeflenen } \\
\text { İhtiyaçlar }\end{array}$ & $\begin{array}{l}\text { Yeni } \\
\text { Fırsatlar }\end{array}$ & $\begin{array}{l}\text { Kültürlerarası } \\
\text { Eğitim }\end{array}$ \\
\hline Estonya & 50 & 90 & 40 & 50 \\
İngiltere & 42 & 67 & 30 & 90 \\
Hollanda & 50 & 60 & 10 & 80 \\
Danimarka & 42 & 90 & 45 & 20 \\
Lüksemburg & 42 & 57 & 25 & 70 \\
Avusturya & 58 & 43 & 35 & 50 \\
\hline
\end{tabular}




\begin{tabular}{lllll}
\hline Almanya & 50 & 47 & 50 & 40 \\
\hline
\end{tabular}

Kaynak: MIPEX verilerine dayanılarak yazar tarafından derlenmiștir.

\section{Avrupa'da Ayırımcı Eğitim Politikaları}

MIPEX verilerine dahil olan ülkelerin en az birinde olmak üzere uygulanan en olumsuz politikalar, diğer bir deyişle en kötü senaryoya göre okullar göçmen öğrencilerin entegrasyonu için bir motor işlevi görmemektedir. Ülkede yaşayan birçok çocuğun tam bir eğitim hakkı yoktur. Sadece birkaç okul veya ad hoc projesi entegrasyonla uğraşır. Çoğu zaman, göçmen bir çocuk aynı yaştaki herkes gibi görülür. Göçmen çocuklar sıklıkla öğretmenleri tarafından problem olarak görülür. Dil desteği olmadığı ya da yetersiz olduğu için hem ailesinin hem de ev sahibi toplumun dilini asla düzgün bir şekilde öğrenemez. Göçmen çocukları düşük performans gösteren okullarda diğer göçmen öğrencilerle birlikte olumsuzluklara terkedilir. Öğretmenler ve çalışanlar da okullarındaki çeşitliliği idare edecek bir eğitim almamışlardır. Bu nedenle vatandaşlar da dahil olmak üzere öğrenciler farklı geçmişlere sahip insanlara saygı duymayı ve onlarla birlikte çalışmayı öğrenmez (MIPEX, 2015C).

Anılan özellikleri taşıyan ülkelerin eğitim göstergeleri açısından dışlayıcı bir nitelikte olması kendilerinin kademeli ayırımcı model içinde değerlendirilmesine için vermektedir. Üçüncü grup ülkeler son gruba nispeten daha az ayırımcıdır. Çek Cumhuriyeti (38), İspanya (37), Yunanistan (36), Fransa (36), italya (34), İrlanda (30) Slovenya (26), Slovakya (24) ülkelerinin içinde yer aldığı üçüncü grupta göçmenlerin eğitime erişim politikalarında en iyi ülke Fransa'da (Tablo 4), okullar ve yerel yetkililer göçmen öğrencilerin eğitimi ve okul yaşamının çeşitliliğe uyarlanıp uyarlanmayacağı konusunda takdir yetkisine sahiptirler (MIPEX, 2015n). Ayırımcı modelin tanımına uygun bir şekilde kültürel çeşitlilikler göz ardı edilirken, siyasal olarak tanımlanan yurttaşlık vurgusu öne çıkarılmaktadır. Bu nedenle Fransız cumhuriyetçi entegrasyon modelinin asimilasyonist bir karaktere sahip olduğu belirtilmektedir (Kaya, 2008: 43). Üçüncü grubun diğer ülkelerinde eğitime erişim ve yeni fırsatların değerlendirilmesi politikalarında oldukça yetersiz oldukları görülmektedir. Buna rağmen Fransa'nın en düşük skora sahip olduğu kültürlerarası eğitim konusunda ülkelerin orta düzeye sahip olduğu görülmektedir. Bu politika alanında en yüksek skoru elinde tutan Slovakya'da kültürlerarası eğitim politikaları kapsamında müfredatlar çokkültürlü eğitim konusunu gözeterek oluşturulmaktadır. Ancak sadece ikamet izni bulunan göçmenlerin çocukları tam eğitime erişebilmekte ve sığınmacı çocuklar ile insan ticareti mağdurları için koruyucu önlemler bulunmaktadır (MIPEX, 20150).

Tablo 4. Üçüncü Grup Ülkelerin Göçmen Eğitim Gösterge Skorları.

\begin{tabular}{|c|c|c|c|c|}
\hline \multirow[t]{2}{*}{ Ülke } & \multirow[t]{2}{*}{ Erişim } & Hedeflenen & Yeni & Kültürlerarası \\
\hline & & İhtiyaçlar & Firsatlar & Eğitim \\
\hline
\end{tabular}




\begin{tabular}{lllll}
\hline Ç.Cumhuriyeti & 33 & 60 & 20 & 40 \\
İspanya & 42 & 37 & 30 & 40 \\
Yunanistan & 50 & 23 & 30 & 40 \\
Fransa & 58 & 30 & 25 & 30 \\
İtalya & 25 & 60 & 10 & 40 \\
İlanda & 25 & 47 & 0 & 50 \\
Slovenya & 33 & 17 & 15 & 40 \\
Slovakya & 17 & 20 & 0 & 60 \\
\hline
\end{tabular}

Kaynak: MIPEX verilerine dayanılarak yazar tarafından derlenmiştir.

Kademeli ayırımcı eğitim modelinin son grubunda yer alan ülkeler Romanya (20) Polonya (20), Malta (19), Litvanya (17), Letonya (17), Hırvatistan (15), Macaristan (15), Bulgaristan'dır (3). Dört politika alanı üzerinden en yüksek skora sahip olan Romanya'nın ortalamasını diğerleri karşısında yükselten politika alanı hedeflenen ihtiyaçlardır (Tablo 5). Ülkede zorunlu eğitim alan bütün öğrencilere dil desteği sağlanmaktadır. Okullar göçmenler konusunda profesyonel destek almaktadır. Ancak okullarda kültürel entegrasyonu arttırmak için herhangi bir politika söz konusu değildir. Göçmen ailelerinin okul hayatına dâhil olacağı destek programları bulunmamaktadır (MIPEX, 2015ö). Dördüncü grubun tüm ülkelerinde orta düzeyde skorun yakalandığı tek politika alanı kültürlerarası eğitimdir. Malta ve Hırvatistan'da okulların kültürlerarası eğitime ve çeşitliliğe uygun hale getirilmesine ilişkin politikaları diğerleri karşısında nispeten olumludur (MIPEX, 2015p; Crotia, 2015r). Ancak grubun tüm ülkelerinde eğitime erişim ve yeni fırsatların değerlendirilmesine yönelik politikaların oldukça dışlayıcı olduğu görülmektedir. Avrupa'da ve MIPEX'e tabi tüm ülkeler içinde en kötü skora sahip olan Bulgaristan'da göçmenlerin eğitim olanaklarından faydalanmaları oldukça güçtür. Okullarda kültürlerarası eğitim anlayışının olduğu belirtilse de uygulamada bunun yansımalarını görmek mümkün değildir. Göçmen öğrencilerin kendi dillerini öğrenmelerini sağlayacak bir ortam olmadığı gibi göçmenler Bulgar dilini öğrenecek etkili destek programlarından yoksundurlar (MIPEX, 2015s). Genel olarak değerlendirildiğinde dördüncü grup ülkelerin göçmen entegrasyonu konusunda eğitimi bir araç olarak kullanma konusunda isteksiz ve ayırımcı oldukları görülmektedir.

Tablo 5. Dördüncü Grup Ülkelerin Göçmen Eğitim Gösterge Skorları.

\begin{tabular}{lllll}
\hline Ülke & Erişim & $\begin{array}{l}\text { Hedeflenen } \\
\text { intiyaçlar }\end{array}$ & $\begin{array}{l}\text { Yeni } \\
\text { Fırsatlar }\end{array}$ & $\begin{array}{l}\text { Kültürlerarası } \\
\text { Eğitim }\end{array}$ \\
\hline Romanya & 8 & 63 & 0 & 10 \\
Polonya & 17 & 23 & 20 & 20 \\
\hline
\end{tabular}




\begin{tabular}{lllll}
\hline Malta & 17 & 20 & 0 & 40 \\
Litvanya & 8 & 30 & 0 & 30 \\
Letonya & 17 & 17 & 15 & 20 \\
Hirvatistan & 8 & 13 & 0 & 40 \\
Macaristan & 0 & 30 & 30 & 0 \\
Bulgaristan & 0 & 0 & 0 & 10 \\
\hline
\end{tabular}

Kaynak: MIPEX verilerine dayanılarak yazar tarafından derlenmiştir.

\section{Sonuç}

Uluslararası göç dünyanın birçok yerinde kalıcı değişikliklere neden olmakta ve siyaseti yeniden biçimlendirmektedir. Sınır güvenliğinin sağlanmasından göçmenleri vardıkları ülke toplumuna uyumlaştırmaya kadar birçok sorun artan göç hacmiyle birlikte daha görünür olmuştur. Göçü yönetilebilir kılmak ve özellikle insan hakları temelinde ortak bir mülteci rejimi tesis etmek için yapılan uluslararası çağrılar ulus devletlerin direnciyle karşılaşmaktadır (Erat, 2017). Her devlet egemenlik temelinde göç gibi hassas politikalarını kendisi oluşturmak istemektedir. Bu nedenle her ne kadar popülerliği hem akademik yazında hem de siyaset söylemlerinde artsa da uluslararası girişimlere rağmen entegrasyon kavramı farklı biçimlerde yorumlanabilmektedir. Devletler göçmenlerin vardıkları ülkeye uyum sağlayabilmenin yollarını ararken bir dizi yol kullanmaktadırlar. Göçmeni ilgilendiren her politika entegrasyonun kucaklayıcı uyumdan dışlayıcı asimilasyona varıncaya kadar yapılan tanımlamalarından birine tekabül etmektedir. Bu da göç özelinde devletlerin tanımlanması sorusunu gündeme getirmektedir.

$\mathrm{Bu}$ bağlam gözetilerek eğitim politikaları üzerinden geliştirilen entegrasyon politikalarını konu eden çalışmada Avrupa ülkelerinin ikiye ayırıldığı görülmektedir. İsveç, Norveç, Portekiz, Belçika, Finlandiya'nın içinde yer aldığı birinci grup ve Estonya, İngiltere, Hollanda, Danimarka, Lüksemburg, Avusturya ve Almanya'nın içinde yer aldığı ikinci gruptaki ülkeler göçmenlerin eğitimle entegrasyonuna sıcak yaklaşmakta ve bu bağlamda diğerleri karşısında etkili politikalar geliştirmektedir. Resmi bir belgeleri olmaksızın ve ayırt edilmeksizin göçmen çocuklarının farklı düzeylerde eğitim olanaklarına erişmesi kolaydır. Göçmelerin gittiği okullarda görev yapan öğretmenler çeşitlilik konusunda belirli eğitimlere tabi tutulmakta ve okullar bu olgu gözetilerek eğitim vermektedirler. Göçmenler okul dışında dil destekleri alabilmekte ve müfredatlar kültürel çeşitliliğe saygı duyacak biçimde kurgulanmaktadır. Bu nedenle her iki grupta yer alan ülkelerin çokkültürlü modele uygun politikalar geliştirdiği söylenebilir. Bu ülkelerde eğitim sivil topluma katılmanın önemli bir yoludur. 
Diğer taraftan Çek Cumhuriyeti, İspanya, Yunanistan, Fransa, İtalya, İrlanda, Slovenya ve Slovakya'nın içinde yer aldığı üçüncü grup ve Romanya, Polonya, Malta, Litvanya, Letonya, Hırvatistan, Macaristan ve Bulgaristan'ın içinde yer aldığı dördüncü grup ülkelerinin eğitimle entegrasyon konusunda dışlayıcı bir tutum sergiledikleri görülmektedir. Bu ülkelerde göçmenlerin eğitim olanaklarına erişimi oldukça zordur. İkili anlaşmaların yapıldığı ülkelerden gelenler ve göçmenler içinde mülteci gruplar gibi ayırımlarla göçmenlere farklı tutumlar geliştirilebilmektedir. Göçmenlerin geçmişte aldıkları eğitimlerin değerlendirilmesi konusunda isteksizlik söz konusudur. Göçmen rehberlik hizmetleri sınırlıdır ve dil destekleri oldukça zayıftır. Bu ülkelerde eğitim alanı sivil topluma entegre olmanın bir yolu değildir. Anılan nedenler ülkelerin ayırımcı model içerisinde değerlendirilmesini mümkün kılmakta hatta asimlasyoncu olup olmadıklarını düşündürmektedir. Genel olarak değerlendirildiğinde Avrupa devletleri; hedeflenen ihtiyaçlar ve kültürlerarası eğitim boyutlarında olumlu; buna karşın eğitime erişim ve yeni fırsatlar boyutlarında olumsuz politikalar geliştirmektedir.

\section{Kaynakça}

Akşar, M. (2016). Kültürel Başkalaşım. Referans, 4(27), 8-12.

Castles, S., \& Miller, M. J. (2008). Göçler Çağı Modern Dünyada Uluslararası Göç Hareketleri. (B. U. Bal, \& İ. Akbulut, Çev.) İstanbul: İstanbul Bilgi Üniversitesi Yayınları.

Castles, S., Korac, M., Vasta, E., \& Vertovec, S. (2002). Integration: Mapping Field. UK: Immigration Research and Statistics Service (IRSS).

Crotia. (2015r). 09 26, 2018 tarihinde Migrant Integration Policy Index: http://www.mipex.eu/croatia adresinden alındı

Demirkanoğlu, Y. (2017). Avrupa'da Göçmenlerin Siyasal Katılımı. Turgut Özal Uluslararası Ekonomi ve Siyaset Kongresi (s. 258-275). Malatya: İnönü Üniversitesi.

Erat, V. (2017). Küreselleşme ve Ulus Devlet Sarmalında Devletlerin Göçmen Politikası. KAUJEASF, 8(15), 197-209.

Erat, V., \& Özkaya, Y. (2017). Vatandaşlığa Erişim Politikalarında Karşılaştırmalı Bir İnceleme: Portekiz, İsveç, İrlanda, Japonya, Estonya. Turgut Özal Uluslararası Ekonomi ve Siyaset Kongresi (s. 1274-1290). Malatya: İnönü Üniversitesi.

European Union. (2017). Migrant Integration. Luxemburg: Publications O ce of the European Union.

Gordon, M. (1964). Assimilation in American Life. Oxford: Univesity Press.

IOM. (2018). International Organization For Migrant. o9 30, 2018 tarihinde Migration and Migrants: A Global Overview: http://www.iom.int/wmr/chapter-2 adresinden alındı

Jacobs, D. (2013). The Educational Integration of Migrants. What is the Role of Sending Society Actors and is there a Transnational Educational Field? San Domenico: European University Institute. 
Kaya, A. (2008). Fransa-Türkleri: Cumhuriyetçi Entegrasyon Modelinin Eleştirisi .

D. Danış, \& V. İrdiş içinde, Türkiye'den Fransa'ya Göç ve Göçmenlik Halleri (s. 36-72). İstanbul: İstanbul Bilgi Üniversitesi Yayınları.

Keskin, H. (2011). Türklerin Gölgesinde Almanya. İstanbul: Doğan Kitap.

Koçak, O., \& Gündüz, R. D. (2017). Avrupa Birliği Göç Politikaları ve Göçmenlerin Sosyal Olarak içerilmelerine Etkisi. Yalova Sosyal Bilimler Dergisi, 7(12), 66-91.

Martikainen, T. (2010). Din, Göçmenler ve Entegrasyon. M.Ü. Iliilıiyaı Fakültesi Dergisi(38), 263-276.

MIPEX. (2015a). What is MIPEX. 9 15, 2018 tarihinde Migrant Integration Policy Index: http://www.mipex.eu/what-is-mipex adresinden alındı

MIPEX. (2015b). Migrant Integration Policy Index 2015. Barcelona: Barcelona Center for International Affairs.

MIPEX. (2015C). Education. 9 15, 2018 tarihinde Migrant Integration Policy Index: http://www.mipex.eu/education adresinden alındı

MIPEX. (2015d). Key Finding. 9 17, 2018 tarihinde Migrant Integration Index: http://www.mipex.eu/key-findings adresinden alındı

MIPEX. (2015e). Migrant Integration Policy Index. 09 27, 2018 tarihinde Sweden: http://www.mipex.eu/sweden adresinden alındı

MIPEX. (2015f). Norway. 9 27, 2018 tarihinde Migrant Integration Policy Index: http://www.mipex.eu/norway adresinden alındı

MIPEX. (2015g). Portugal. 09 25, 2018 tarihinde Migrant Integration Policy Index: http://www.mipex.eu/portugal adresinden alındı

MIPEX. (2015h). Belgium. 09 25, 2018 tarihinde Migrant Integration Policy Index: http://www.mipex.eu/belgium adresinden alındı

MIPEX. (2015i). Finland. 09 25, 2018 tarihinde Migrant Integratio Policy Index: http://www.mipex.eu/finland adresinden alındı

MIPEX. (2015j). Estonia. 9 25, 2018 tarihinde Migrant Integration Policy Index: http://www.mipex.eu/estonia\#/tab-education adresinden alındı

MIPEX. (2015k). Denmark. 09 25, 2018 tarihinde Migrant Integration Policy Index: http://www.mipex.eu/denmark adresinden alındı

MIPEX. (2015I). United Kingdom. 09 25, 2018 tarihinde Migrant Integration Policy Index: http://www.mipex.eu/united-kingdom adresinden alındı

MIPEX. $\quad(2015 \mathrm{~m}) . \quad 09 \quad 25, \quad 2018$ tarihinde Netherlands: http://www.mipex.eu/netherlands adresinden alındı

MIPEX. (2015n). French. og 25, 2018 tarihinde Migrant Integration Policy Index: http://www.mipex.eu/france adresinden alındı

MIPEX. (20150). Slovakia. 09 25, 20180 tarihinde Migrant Integration Policy Index: http://www.mipex.eu/slovakia adresinden alındı

MIPEX. (20150̈, 09 26). Romania. Migrant Integrational Index: http://www.mipex.eu/romania adresinden alındı

MIPEX. (2015P). Malta. 09 26, 2018 tarihinde Migrant Integration Policy Index: http://www.mipex.eu/malta adresinden alındı

MIPEX. (2015s). Bulgaria. og 26, 2018 tarihinde Migrant Integration Index: http://www.mipex.eu/bulgaria adresinden alındı 
MIPEX. (2018, 9 30). List Of Indicators. Migrant Integration Policy Index: http://www.mipex.eu/sites/default/files/downloads/pdf/files/custom/a4/2018 .09.30-22.28.19-mipex-2015-custom-book-a4.pdf adresinden alındı

OECD\& European Union. (2015). Indicators of Immigrant Integration 2015: Settling In. Paris: OECD Publishing.

Oxford. (2018, 09 21). integrate. Oxford Living Dictionaries: https://en.oxforddictionaries.com/definition/integrate adresinden alındı

Özmen, N. (2012). Çokkültürlü Toplumda Sosyal Entegrasyon ve Din. İstanbul: Çamlıca Yayınları .

Özservet, Y. Ç. (2015). Göçmen Çocukların Şehre Uyumu ve Eğitim Politikası. Y. Bulut içinde, Uluslararası Göç ve Mülteci Uyumu Sorununda Kamu Yönetiminin Rolü (s. 93-111). Kocaeli: Umuttepe Yayınları.

Şahin, B. (2010). Almanya'daki Türk Göçmenlerin Sosyal Entegrasyonunun Kuşaklar Arası Karşılaştırması: Kültürleşme. Bilig(55), 103-134.

TDK. (2018, 09 21). Genel Türkçe Sözlük. entegrasyon: http://tdk.gov.tr/index.php?option=com_gts\&arama=gts\&guid=TDK.GTS.5ba 577b953e623.85974879 adresinden alındı

UNESCO. (2017). Migration and Education. 9 16, 2018 tarihinde https://es.unesco.org/gem-report/sites/gem-report/files/Think\%20piece\%20\%2olnternational\%2omigration\%20and\%20education\%20-\%20Tani\%20-

ö 94 \%20FINAL.pdf adresinden alındı

Unutulmaz, K. O. (2015). Gündemdeki Kavram "Göçmen Entegrasyonu"Avrupa'daki Gelişimi ve Britanya Örneği. S. G. Öner, \& N. A. Öner içinde, Küreselleşme Çağında Göç (s. 135-159). İstanbul: İletişim Yayınları.

Yıldız, A. (2017). Göç ve Entegrasyon Politikalarında Vatandaşlık. Göç Araştırmaları Dergisi, 3(1), 36-67.

Yontar, i. G., \& Savut, E. (2018). Seçilmiş Avrupa Ülkeleri ve Türkiye'de Göçmenlerin Siyasal Katılımı. Yönetim Bilimleri Dergisi,, 14(28), 251-288. 